\title{
Effects of carbofuran and metsulfuron-methyl on the benthic macroinvertebrate community in flooded ricefields
}

\author{
Efeito do carbofurano e metsulfuron-methyl sobre a comunidade \\ de macroinvertebrados bentônicos de lavoura de arroz irrigado
}

\section{Joele Baumart, Marcelo Dalosto and Sandro Santos}

Programa de Pós-Graduação em Biodiversidade Animal, Centro de Ciências Naturais e Exatas,

Departamento de Biologia, Laboratório de Carcinologia, Universidade Federal de Santa Maria - UFSM, CEP 97105-900, Santa Maria, RS, Brazil

e-mail: jobaumart@gmail.com,marcelo.dalosto@gmail.com, ssantos@smail.ufsm.br

\begin{abstract}
Aim: This study evaluated the effect of the insecticide carbofuran and the herbicide metsulfuron-methyl on the abundance and diversity of benthic macroinvertebrates in a paddy ricefield. Methods: To achieve this goal, two pesticide treatments [the insecticide carbofuran (IC) and the herbicide metsulfuron-methyl (HM)] and a control (Co) treatment with no added pesticide were established in an experimental area of the Plant Science Department of the Federal University of Santa Maria. Soil samples were collected in triplicate from each treatment 30 days before and 1, 10, and 51 days after the pesticide application, for macrofauna identification. Results: Among the 21 taxa identified, Trichoceridae was present only in Co, Hydroptilidae was recorded only in IC, and Corixidae in HM. In Co, the most abundant group was Annelida, while in IC and HM Diptera (Chironomidae) was dominant. Significant differences were observed between Co and IC, in the density of Odontoceridae (Control>IC) and Hydrophilidae (Control<IC), and between Co and HM in the density of Odontoceridae (Control>HM) and Hirudinea (Control<HM). Conclusion: In spite of the possible negative effects of the pesticides on the benthic community, the assemblages recovered rapidly.
\end{abstract}

Keywords: environmental impact, density, benthic community, biomonitoring, pesticides.

Resumo: Objetivo: O objetivo desse estudo foi avaliar o efeito do inseticida carbofurano e do herbicida metsulfuron-methyl na abundância e diversidade de macroinvertebrados bentônicos em campo de arroz irrigado. Métodos: Para isto, dois tratamentos com agrotóxicos [o inseticida carbofurano (IC) e o herbicida metsulfuronmethyl (HM)] e um controle (Co), tratamento sem pesticida, foram aplicados em uma área experimental no Departamento de Fitotecnia da Universidade Federal de Santa Maria. Amostras de solo foram coletadas em triplicatas em cada tratamento 30 dias antes (DBA) e 1, 10 e 51 dias após a aplicação dos pesticidas, posteriormente a macrofauna foi identificada. Resultados: Vinte e um (21) taxa foram identificados, entre esses Trichoceridae esteve presente apenas em Co, enquanto que Hydroptilidae foi coletado apenas em IC, e Corixidae em HM. Em Co e IC, o grupo mais abundante foi Annelida, e em HM foi Diptera (Chironomidae) que prevaleceu. Diferenças significativas foram observadas entre Co e IC, na densidade de Odontoceridae (Co>IC) e Hydrophilidae ( $\mathrm{Co}<\mathrm{IC})$, e entre Co e HM na densidade de Odontoceridae (Co>HM) e Hirudinea $(\mathrm{Co}<\mathrm{HM})$. Conclusáo: Entretanto, apesar dos possíveis efeitos negativos dos pesticidas sobre a comunidade bentônica verificados nos primeiros dias após a aplicaçáo, verificou-se que de forma geral a comunidade recuperou-se rapidamente.

Palavras-chave: impacto ambiental, densidade, comunidade bentônica, biomonitoramento, agrotóxicos. 


\section{Introduction}

Flooded rice is an important crop in southern Brazil. Ricefields cover an area of about 1 million hectares in the state of Rio Grande do Sul, where $60 \%$ of the national rice crop is produced (CONAB, 2006). During the rice-growing season from October to March (austral spring and summer), the flooding system creates immense shallow lakes in these lowland areas. In general, these conditions are ideal for the establishment of many aquatic organisms and others that live associated with them, but some are considered pests in rice crops, such as certain coleopterans (Curculionidae) and dipterans (Chironomidae), among others (Sosbai, 2010; Halwart, 2006).

To maximize rice yields, sustainable management of the crop is needed to control the main pests that limit rice growth and development. It is necessary to use pesticides, including herbicides, fungicides, and insecticides (Nakagome et al., 2006). In recent years, the insecticide carbofuran (2,3-dihydro-2-2 dimethyl-7- benzofuranyl methylcarbamate), commercial brand Furadan $100 \mathrm{G}^{\circ}$, has been among the most often used. However, its fate in aquatic systems continues to be almost unknown (NRCC, 1979), and a better understanding of its effects on these ecosystems is necessary (Wayland and Boag, 1995). The herbicide metsulfuron-methyl \{methyl 2[[[[(4-methoxy-6-methyl-1,3,5-triazin2-yl)amino]carbonyl]amino] sulfonyl] benzoate\}, commercial brand Ally, is widely used in rice crops to control broadleaf weeds (Rodrigues and Almeida, 2005). Investigation of these pesticides is of the utmost importance for a better understanding of their dynamics in the environment.

For aquatic organisms, ricefields are an extreme environment with regard to the abiotic conditions (Fernando, 1993), and invertebrates need special adaptations to survive in this environment (Williams, 1987). According to Mesléard et al. (2005), although many studies have demonstrated the negative effects of pesticides on aquatic communities, they deal mainly with certain specific species of chironomids. Studies with macroinvertebrates in rice crops are still insufficient to fully clarify the cost-benefit relationships of using or not using these products.

Benthic macroinvertebrates are one of the main groups of organisms used to evaluate environmental impacts and for biological monitoring in aquatic ecosystems (Goulart and Callisto, 2003). These organisms spend all or part of their life cycles in the sediments of these environments, associated with different substrates, both organic and inorganic. Therefore, the benthic macroinvertebrate communities express the ecological conditions of aquatic ecosystems in which they live (Morgan et al., 2006). Even though they are not natural wetlands, irrigated ricefields can be suitable for many aquatic organisms, thus contributing to the conservation of biodiversity (Halwart, 2006; Stenert et al., 2009, Machado and Maltchik, 2010). The aim of this study was to evaluate the impacts of the insecticide carbofuran and the herbicide metsulfuron-methyl on the benthic macroinvertebrate community in paddy ricefields. This study is justified by the fact that, even though it is known that pesticides can damage adjacent communities, it is still little understood how these communities, in this case the benthic community, specifically respond to these pesticides.

\section{Material and Methods}

The study was conducted in an experimental floodplain rice area of the Plant Science Department (Federal University of Santa Maria), during the 2005/06 season. The soil is a planosoil with medium texture and flat relief, and the substrate is a recent alluvial deposit (EMBRAPA, 1999); the altitude is $95 \mathrm{~m}$. The climate is humid subtropical, Cfa classification, with an annual mean rainfall of $1616 \mathrm{~mm}$.

The experimental design consisted of three blocks $(8 \times 6 \mathrm{~m}$ each) with three treatments: Control (no treatment), carbofuran (IC) (Furadan $100 \mathrm{G}^{\circ}$, at a dose of 400 g.a.i.ha ${ }^{-1}$ ), and metsulfuron-methyl (HM) (Ally, at a rate of 2 g.a.i.ha ${ }^{-1}$ ), according to technical recommendations (Sosbai, 2005). In each treatment, three soil samples were taken randomly, using a core sampler $\left(0.01 \mathrm{~m}^{2}\right.$ in area $0.1 \mathrm{~m}$ high). Sampling was carried out 30 days before the pesticide application (DBA), and 1, 10, and 51 days after the pesticide application (DAA). At 30 DBA, the rice seedlings were in the three-leaf growth stage; between 1 and 10 DAA, they were in an intermediate growth stage; and at 51 DAA, the grains were swelling. In the laboratory, the soil samples were washed on a $0.25 \mathrm{~mm}$ sieve, and the macroinvertebrates were placed in plastic bottles, stained with Rose Bengal, and after one hour were fixed with absolute ethyl alcohol. The material was identified at the lowest possible taxonomic level using a stereomicroscope and appropriate identification keys (Costa et al., 2006; Fernández and Domínguez, 2001; Pereira et al., 2000) and then stored in $70 \%$ ethyl alcohol. 
During the experiments, $\mathrm{pH}$ was measured with a Hanna $\mathrm{pH}$ meter (HI 8424), and temperature and dissolved oxygen (DO) were measured with an YSI oxygen meter (model Y5512). The results for macroinvertebrate densities were submitted to a two-way Analysis of Variance (ANOVA), to evaluate the interaction between treatment and sampling time. The means were compared through a Tukey Test $(\mathrm{p}<0.05)$ to determine the differences among the treatments. An ANOSIM was performed to determine whether the community composition was similar between treatments on the four sampling dates. The Bray-Curtis index was used to construct the similarity matrix. For these analyses, the programs PAST 1.82b (Hammer et al., 2001) and BioEstat 5.0 (Ayres et al., 2007) were used.

\section{Results}

A significant difference was found for DO among the treatments and the sampling dates, whereas $\mathrm{pH}$ and temperature only showed a difference among the sampling dates (Table 1). The concentration of dissolved oxygen was low, probably because of the shallow water that was maintained at a depth $10 \mathrm{~cm}$ throughout the experiment.

Twenty-one taxa were identified (Table 2). Of these, Diptera: Trichoceridae was recorded only in Co (30DBA), Trichoptera: Hydroptilidae was present only in IC (30DBA), and Hemiptera: Corixidae was found only in HM (51DAA). Of the other 17 taxa, Diptera: Chironomidae was abundant in all treatments and at all sampling times, as were annelids, represented by Oligochaeta. Probably, taxa were present that were either sensitive or tolerant to the pesticides tested. Thus, the sensitive taxa appeared in the control treatment, while the resistant ones were present in the treatments with pesticides. As an example, tabanid dipterans were present in the control and IC, but were recorded only in the 30DBA sampling, showing sensitivity to the herbicide (Table 2). Predators such as odonates were present in all three treatments during most of the experiment, thus showing tolerance to the pesticides (Table 2). Some taxa were likely favored over others.

The ANOSIM showed differences in the community composition between treatments $(\mathrm{R}=0.278)$; however, these differences were not significant $(p>0.05)$ for any treatment or sampling time.

On the first sampling date (30 DBA), there was no significant difference in the density of organisms among treatments. However, in the IC treatment at 1 DAA sampling, the mean density of organisms was lower than in the control $(\mathrm{p}<0.05)$. On average, the second sampling showed higher organism densities than the sample before the pesticide application, for the control treatment (Figure 1).

At 10 DAA, the mean density in the control increased again, but did not differ significantly from 1 DAA. However, for HM, the mean density decreased, and showed differences from the control. The IC was also significantly different from the

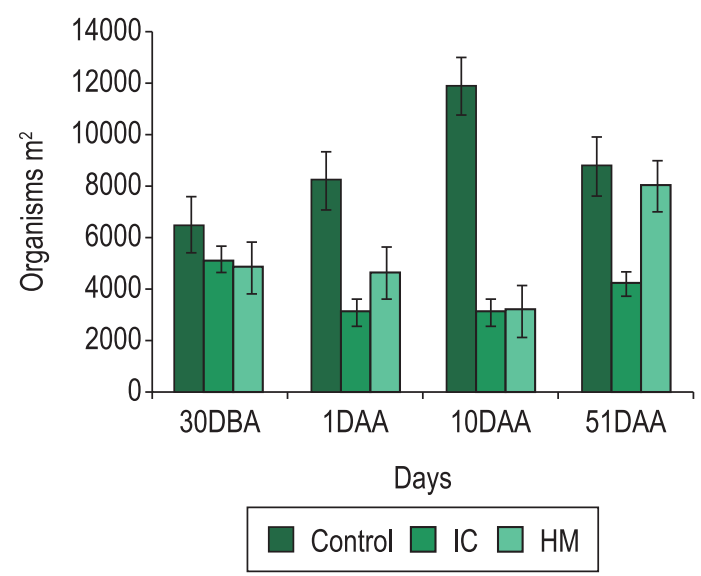

Figure 1. Mean density of organisms found on each sampling date. Control: control treatment without pesticide application; IC: Insecticide treatment; HM: Herbicide treatment. Bars represent the standard deviation. (DBA: days before application; DAA: days after application of the pesticides).

Table 1. Levels of dissolved oxygen (DO), $\mathrm{pH}$, and temperature $\left(\mathrm{T}^{\circ} \mathrm{C}\right)$ of the rice paddy water at each sampling time, Santa Maria, Rio Grande do Sul, Brazil, 2006.

\begin{tabular}{|c|c|c|c|c|c|c|c|c|c|}
\hline Sampling & \multicolumn{3}{|c|}{$\mathrm{DO}\left(\mathrm{mg} \cdot \mathrm{L}^{-1}\right)$} & \multicolumn{3}{|c|}{$\mathrm{pH}$} & \multicolumn{3}{|c|}{$\mathrm{T}^{\circ} \mathrm{C}$} \\
\hline Time & Control $^{1}$ & IC & $\mathrm{HM}$ & Control & IC & $\mathrm{HM}$ & Control & IC & $\mathrm{HM}$ \\
\hline 30 DBA & $2.12^{\mathrm{A}}$ & $2.04^{\mathrm{aB}}$ & $2.04^{\mathrm{aB}}$ & $6.77^{\mathrm{a}}$ & $6.71^{a}$ & $6.79^{a}$ & $23.8^{c}$ & $24.0^{c}$ & $23.6^{c}$ \\
\hline $1 \mathrm{DAA}$ & $2.08^{A}$ & $1.97^{\mathrm{aB}}$ & $1.94^{\mathrm{aB}}$ & $6.62^{\mathrm{a}}$ & $6.67^{a}$ & $6.69^{a}$ & $26.0^{b}$ & $26.2^{b}$ & $25.8^{b}$ \\
\hline 10 DAA & $1.98^{\mathrm{A}}$ & $1.68^{\mathrm{cB}}$ & $1.7^{\mathrm{cB}}$ & $6.40^{c}$ & $6.36^{c}$ & $6.35^{\circ}$ & $27.1^{a}$ & $27.4^{\mathrm{a}}$ & $27.0^{\mathrm{a}}$ \\
\hline $51 \mathrm{DAA}$ & $2.01^{A}$ & $1.86^{\mathrm{bB}}$ & $1.87^{\mathrm{bB}}$ & $6.59^{b}$ & $6.47^{b}$ & $6.47^{b}$ & $25.3^{b}$ & $26.1^{\mathrm{b}}$ & $25.7^{\mathrm{b}}$ \\
\hline
\end{tabular}

${ }^{1} \mathrm{CT}$ : control treatment; IC: treatment with insecticide and HM: treatment with herbicide; DBA: days before pesticide application; DAA: days after pesticide application. Capital letters represent significant differences among the treatments, and lower-case letters represent significant differences among the sampling times, by Tukey Test $(\mathrm{p}<0.05)$. 
Table 2. Mean density of organisms per $\mathrm{m}^{2}$ in each treatment and at each sampling time. Santa Maria, Rio Grande do Sul, Brazil, 2006.

\begin{tabular}{|c|c|c|c|c|c|c|c|c|c|c|c|c|}
\hline \multirow[t]{2}{*}{ Taxa } & \multicolumn{4}{|c|}{ Control $^{1}$} & \multicolumn{4}{|c|}{ IC } & \multicolumn{4}{|c|}{ HM } \\
\hline & $30 \mathrm{DBA}$ & $1 \mathrm{DAA}$ & 10 DAA & 51 DAA & $30 \mathrm{DBA}$ & $1 \mathrm{DAA}$ & 10 DAA & 51 DAA & $30 \mathrm{DBA}$ & 1DAA & 10 DAA & $51 \mathrm{DAA}$ \\
\hline \multicolumn{13}{|l|}{ ARTHROPODA } \\
\hline \multicolumn{13}{|l|}{ INSECTA } \\
\hline \multicolumn{13}{|l|}{ Coleoptera } \\
\hline Curculionidae & 0 & 266.66 & 133.33 & 0 & 0 & 100 & 0 & 0 & 0 & 0 & 66.66 & 0 \\
\hline Hydrophilidae & 33.33 & 33.33 & 0 & 33.33 & 66.66 & 133.33 & 33.33 & 66.66 & 33.33 & 0 & 0 & 100 \\
\hline \multicolumn{13}{|l|}{ Diptera } \\
\hline Ceratopogonidae & 500 & 800 & 1200 & 466.66 & 1066.7 & 266.66 & 100 & 233.33 & 833.33 & 466.7 & 66.66 & 1266.66 \\
\hline Chironomidae & 2100 & 1866.66 & 1566.66 & 1400 & 2033.3 & 700 & 566.66 & 1666.7 & 2000 & 1033 & 1233.3 & 2933.33 \\
\hline Tabanidae & 0 & 33.33 & 66.66 & 66.66 & 33.33 & 0 & 33.33 & 0 & 66.66 & 0 & 0 & 0 \\
\hline Trichoceridae & 66.66 & 0 & 0 & 0 & 0 & 0 & 0 & 0 & 0 & 0 & 0 & 0 \\
\hline \multicolumn{13}{|l|}{ Ephemeroptera } \\
\hline Leptohyphidae & 33.33 & 0 & 0 & 0 & 66.66 & 66.66 & 0 & 300 & 33.33 & 100 & 0 & 0 \\
\hline \multicolumn{13}{|l|}{ Hemiptera } \\
\hline Corixidae & 0 & 0 & 0 & 0 & 0 & 0 & 0 & 0 & 0 & 0 & 0 & 100 \\
\hline \multicolumn{13}{|l|}{ Odonata } \\
\hline Aeshnidae & 0 & 133.33 & 33.33 & 333.33 & 66.66 & 66.66 & 0 & 200 & 300 & 0 & 33.33 & 0 \\
\hline Coenagrionidae & 0 & 0 & 0 & 0 & 66.66 & 66.66 & 0 & 0 & 266.66 & 166.7 & 100 & 0 \\
\hline Gomphidae & 0 & 33.33 & 0 & 0 & 100 & 33.33 & 0 & 0 & 33.33 & 33.33 & 33.33 & 0 \\
\hline Perilestidae & 33.33 & 0 & 0 & 0 & 0 & 0 & 0 & 0 & 66.66 & 0 & 0 & 0 \\
\hline \multicolumn{13}{|l|}{ Trichoptera } \\
\hline Odontoceridae & 1066.7 & 1733.33 & 1833.33 & 866.66 & 366.66 & 766.66 & 933.33 & 666.66 & 333.33 & 833.3 & 366.66 & 566.66 \\
\hline Hydroptilidae & 0 & 0 & 0 & 0 & 33.33 & 0 & 0 & 0 & 0 & 0 & 0 & 0 \\
\hline \multicolumn{13}{|l|}{ CRUSTACEA } \\
\hline Ostracoda & 166.66 & 66.66 & 166.66 & 433.33 & 0 & 0 & 0 & 33.33 & 0 & 100 & 33.33 & 100 \\
\hline \multicolumn{13}{|l|}{ ANNELIDA } \\
\hline Hirudinea & 366.66 & 466.66 & 333.33 & 333.33 & 333.33 & 200 & 166.66 & 100 & 66.66 & 33.33 & 266.66 & 100 \\
\hline Oligochaeta & 400 & 1866.66 & 4900 & 2666.66 & 466.66 & 133.33 & 500 & 600 & 266.66 & 1500 & 466.66 & 2466.66 \\
\hline \multicolumn{13}{|l|}{ MOLLUSCA } \\
\hline \multicolumn{13}{|l|}{ Basommatophora } \\
\hline Planorbidae & 0 & 66.66 & 66.66 & 100 & 0 & 0 & 0 & 33.33 & 33.33 & 33.33 & 33.33 & 0 \\
\hline Bivalvia & 33.33 & 433.33 & 733.33 & 1100 & 0 & 33.33 & 0 & 0 & 0 & 0 & 133.33 & 0 \\
\hline \multicolumn{13}{|l|}{ Gastropoda } \\
\hline \multicolumn{13}{|l|}{ Architaenioglossa } \\
\hline \multicolumn{13}{|l|}{ Ampullariidae } \\
\hline Pomacea sp. & 766.66 & 133.33 & 633.33 & 566.66: & 66.66 & 233.33 & 100 & 333.33 & 200 & 66.66 & 166.66 & 233.33 \\
\hline NEMATODA & 1000 & 333.33 & 300 & 466.66 & 433.33 & 333.33 & 66.66 & 33.33 & 333.33 & 333.3 & 200 & 200 \\
\hline & 6566.7 & 8260.66 & 12940.9 & 8833.28 & 5199.9 & 3133.3 & 2500 & 4266.6 & 4866.6 & 4700 & 3066.6 & 8066.84 \\
\hline
\end{tabular}

${ }^{1}$ Control: control treatment without pesticide application; IC: treatment with insecticide; HM: treatment with herbicide; DBA: days before pesticide application; DAA: days after pesticide application.

control treatment, although there was no increase in the mean density.

On DDA 51 the density increased in the IC and the HM. However, even with this increase, the density of organisms was lower than the IC and $\mathrm{HM}$, probably because the CI treatment is more toxic to aquatic invertebrates in general.

At the family level, Odontoceridae showed significant differences between the control and insecticide treatments. These differences occurred on the first and 10DAA, but did not repeat on day 51, and also between the control and the herbicide treatments (Table 2). Two families belonging to Coleoptera were found: Curculionidae and Hydrophilidae; but only the latter showed significantly higher abundances in IC than in the control. Although the density decreased on 1DAA in the treatments with pesticides, the density had recovered by $10 \mathrm{DDA}$. In the control treatment, this family only appeared up to the second sampling, and the restructuring of the population seen during the treatment with insecticide did not occur in the control treatment (Table 2). The subclass Hirudinea differed significantly in density between the control and herbicide treatments (Table 2). 


\section{Discussion}

The influence of pesticides in reducing water quality was also reported by Molozzi et al. (2006), who evaluated irrigation and drainage water from ricefields. In rice crop areas, the concentration of dissolved oxygen (DO) tends to be low due to the height of the water, usually between 5 and $15 \mathrm{~cm}$. Other studies in the same area reported DO concentrations from 0.6 to $2.2 \mathrm{mg} . \mathrm{L}^{-1}$ (Golombieski et al., 2008), 2.4 to $4.6 \mathrm{mg} . \mathrm{L}^{-1}$ (Reimche et al., 2008) and 2.5 to $11.90 \mathrm{mg} . \mathrm{L}^{-1}$ (Baumart and Santos, 2010). In this study, DO ranged between 1.7 and $2.12 \mathrm{mg} . \mathrm{L}^{-1}$; however, because this difference was recorded before the pesticide application, probably the oxygen levels were not associated with these treatments. The low DO availability may have, however, restricted the colonization of the area by certain taxa that could be present if the DO concentrations were close to saturation, such as reported by Baumart and Santos (2010), who reported a higher diversity of taxa, when only control treatments are compared.

Over time, invertebrates in ricefields under cultivation are expected to increase in absolute abundance and richness, because pesticides tend to degrade in the environment, with a decrease in their toxic effect (Schulz \& Liess, 1999). As seen in other studies (Schulz \& Liess, 1999; Suhling et al., 2000; Baumart and Santos, 2010), with the end of the crop cycle, some taxa recolonized the area, and other groups already present increased in abundance.

For the benthic macroinvertebrate assemblage, in the first sampling (prior to the application of the pesticides) there were no differences among the treatment fields, which was expected. However, the changes seen in the subsequent collections reflected the effects of these products, mainly in the sampling on the first day after the use of pesticides, when the organisms may have suffered from so-called instantaneous stress.

According to Tatum (2004), the most commonly used herbicides, including metsulfuron, are soluble in water and rapidly degrade once they enter the environment. According to the same author, they are neither persistent nor do they bioaccumulate, because modern herbicides have been designed only to act on plants, showing a low level of direct toxicity to animals, such as insects, fish, amphibians, or others, if used correctly. The study by Golombieski (2006), confirmed these data, showing that 12 hours after metsulfuron-methyl was applied; it was not possible to detect it in the water of irrigated rice.
Nevertheless, although it was not identified in the water, from the results obtained in the present study it is possible to infer that this product does influence aquatic invertebrates. Because we are working with benthic organisms, analyses of the accumulation of the product in the sediment would be necessary, but this information is not yet available.

In the subclass Hirudinea, which was recorded in all three treatments, there was a significant difference between the control treatment and the treatment with herbicide. Although these organisms are tolerant to low dissolved-oxygen concentrations, we believe that this factor did not increase the assemblage of hirudineans in HM, because once the effect of the herbicide had passed the population declined, returning to the numbers found in the first, pesticide-free sampling. During their exposure to the herbicide, these organisms probably increased in abundance due to favorable conditions for their development. In studies in Danish rivers (Friberg et al., 2003), where high concentrations of pesticide metabolites were recorded, high densities of Hirudinea were also reported in the spots with a higher concentration of agrotoxins, which may indicate that these organisms are resistant to these compounds. According to Bacey and Spurlock (2007), these favorable conditions may reflect a greater quantity of organic matter, coming from decomposition of organisms affected by the herbicide or from the absence of some competitor or predator.

Michael et al. (1991), in studies in Florida, also reported that metsulfuron does not produce significant or persistent contamination of surface water, and expressed some doubts about its persistence in the soil. Li et al. (2005) reported that this product can damage rice crops, because it affects plant growth, mainly the morphology of the roots, which become smaller and fewer.

According to Nakagome et al. (2006), carbofuran is highly toxic to aquatic organisms, partly because of its low solubility in water, which requires more time for its degradation. Carbofuran is so highly toxic that its active ingredient can be detected in water up to 17 days after its use, in a $0.013 \mathrm{mg} . \mathrm{L}^{-1}$ concentration (Golombieski, 2006). According to Vyas et al. (1998) this insecticide can decrease the efficiency of the enzyme acetylcholinesterase by about $80 \%$ in the brain of birds, which may cause high mortality. This pesticide is highly lipophilic, and accumulates in the fat and mainly in the liver of organisms that ingest it. This is lethal to many animals, including vertebrates, which feed directly 
on contaminated seeds, on the grains of the product itself, and also on invertebrates from the treated area. This latter group includes the target taxa (acarines, insects, and nematodes) as well as the nontarget ones (microcrustaceans, ephemeropterans, plecopterans, odonates) that do not damage the rice crop.

In this study, carbofuran caused a general reduction in the macroinvertebrate assemblage. However, over time, the density of this community recovered. The most critical time for these assemblages was seen on the $10^{\text {th }}$ day, when almost all taxa were considerably reduced. This may have occurred due to scarcity of food for the groups, mainly the predators, in addition to poisoning by the active ingredient of the product, considering that the use of pesticides reduces the availability of food to benthic macroinvertebrates, alters the structure of the algae community, and may also have a toxic effect on these resources (Gagneten, 2002).

Because this was a field experiment, many variables may have influenced the results. However, considering that the entire macrobenthos community was analyzed, it is possible to infer that the use of pesticides had some consequences for the benthic communities, directly through the effects of their active ingredients or indirectly through reduction of oxygen, food, etc. Despite these effects, much of the community recovered with time, returning to the point before the pesticide application. This may occur either because the pesticides do not persist for long in the soil, or because their molecules are absorbed by the soil and are not available to the organisms. The results support the conclusion that other studies, focusing on specific taxonomic groups, are of extreme importance to evaluate the action of these pesticides more directly.

\section{References}

AYRES, M., AYRES JUNIOR, M., AYRES, DL. and SANTOS, AS. 2007. BioEstat 5.0: Aplicações estatísticas nas áreas das ciências biológicas e médicas. Sociedade Civil Mamirauá, Imprensa Oficial do Estado do Pará.

BACEY, J. and SPURLOCK, F. 2007. Biological Assessment of Urban and Agricultural Streams in the California Central Valley. Environmental Monitoring Assessment, vol. 130, p. 483-493. PMid:17072545. http://dx.doi.org/10.1007/s10661-006-9438-8

BAUMART, J. and SANTOS, S. 2010. The Impact of Herbicides on Benthic Organisms in Flooded Rice Fields in Southern Brazil. In: KORTEKAMPS, A., ed. Herbicides and Environment. InTech. p. 369-382.
Companhia Nacional de Abastecimento - CONAB. 2006. Estimativa de safras: 2005/2006. Available from: $<$ http://www.conab.gov.br>. Access in: out. 2006.

COSTA, C., IDE, S. and SIMONKA, CC. 2006. Insetos imaturos. Metamorfose e Identificação. Editora Holus. 249 p.

FERNÁNDEZ, HR. and DOMÍNGUEZ, E. 2001. Guia para la determinación de los artrópodos bentónicos Sudamericanos. Ed. Tucumán: Imprenta Central de la UNT.

FERNANDO, CH. 1993. Rice-field ecology and fish culture an overview. Hydrobiologia, vol. 259, p. 91113. http://dx.doi.org/10.1007/BF00008375

FRIBERG, N., LINDSTRØM, M., KRONVANG, B. and LARSEN, LS. 2003. Macroinvertebrate sediment relationships along a pesticide gradient in Danish streams. Hydrobiologia, vol. 494, p. 103-110. http://dx.doi.org/10.1023/A:1025493627272

GAGNETEN, AM. 2002. Efectos del herbicida paraquat sobre el zooplancton. Iheringia, vol. 92, p. 47-56.

GOLOMBIESKI, JI. 2006. Interação da rizipsicultura com agroquimicos e efeitos sobre a comunidade zooplanctônica. Santa Maria: Universidade Federal de Santa Maria. [Tese de Doutorado em Agronomia].

GOLOMBIESKI, JI., MARCHESAN, E., BAUMART, JS., REIMCHE, GB., RESGALLA JUNIOR , C., STORCK, L. and SANTOS, S. 2008. Cladocers, Copepods and Rotifers in rice-fish culture handled with metsulfuron-methyl and azimsulfuron herbicides and carbofuran insecticide. Ciência Rural, vol. 38, no. 8 , p. 2097-2102. http://dx.doi.org/10.1590/ S0103-84782008000800001

GOUlART, M. and CALListo, M. 2003. Bioindicadores de qualidade de água como ferramenta em estudos de impacto ambiental. Revista da FAPAM, vol. 2, no. 1 .

HALWART, M. 2006. Biodiversity and nutrition in ricebased aquatic ecosystems. Journal of Food Composition and Analysis, vol. 19, p. 747-751. http://dx.doi. org/10.1016/j.jfca.2006.03.012

HAMMER, Ø., HARPER, DAT. and RYAN, PD. 2001. PAST 1.82b. Past: Paleontological Statistics Software package for education and data analysis. Paleontologia Electronica, vol. 4, no. 1, p. 9.

LI, ZJ., XU, JM., MUHAMMAD, A. and MA, GR. 2005. Effect of bound residues of metsulfuron methyl in soil on rice growth. Chemosphere, vol. 58, p. 1177-1183. http://dx.doi.org/10.1016/j. Chemosphere.2004.09.056

MACHADO, IF. and MALTCHIK, L. 2010. Can management practices in rice fields contribute to amphibian conservation in southern Brazilian wetlands? Aquatic Conservation: Marine and Freshwater Ecosystems, vol. 20, p. 39-46.

MESLÉARD, F., GARNERO, S., BECK, N. and ROSECCHI, E. 2005. Uselessness and indirect 
negative effects of an insecticide on rice field invertebrates. Comptes Rendus Biologies, vol. 328, p. 955-962. PMid:16286085. http://dx.doi. org/10.1016/j.crvi.2005.09.003

MICHAEL, JL., NEARY, DG., FISCHER, J. and GIBBS, H. 1991. Metsulfuron in surface groundwater of a north Florida flatwoods. In: Proceedings of the XLIV Southern Weed Science Society Perception: fact or fiction, 1991. Champaign: Southern Weed Science Society.

MOLOZZI, J., PINHEIRO, A. and SILVA, MR. 2006. Qualidade da água em diferentes estádios de desenvolvimento do arroz irrigado. Pesquisa Agropecuária Brasileira, vol. 41, no. 9, p. 1393-1398. http://dx.doi.org/10.1590/S0100204X2006000900007

MORGAN, FL., OLIVEIRA, A. and CALLISTO, M. 2006. Inventory of benthic macroinvertebrates diversity in the Environmental Station Reservoir of Minas Gerais, Brazilian. Neotropical Biology and Conservation, vol. 1, no. 1, p. 17-23.

NAKAGOME, FK., NOLDIN, JA. and RESGALLA JUNIOR, C. 2006. Toxicidade aguda e análise de risco de herbicidas e inseticidas utilizados na lavoura do arroz irrigado sobre o cladócero Daphnia magna. Pesticidas: ecotoxicologia e meio ambiente, vol. 16, p. 93-100.

National Research Council Canada - NRCC. 1979. Carbofuran: Criteria for Interpreting the Effects of its Use on Environmental Quality. Ottawa: National Research Council of Canada, Associate Committee on Scientific Criteria for Environmental Quality. NRCC 16740.

PEREIRA, D., VEITENHEIMER-MENDES, IL., MANSUR, MCD. and SILVA, CP. 2000. Malacofauna límnica do sistema de irrigação do Arroio Capivara, Triunfo, RS, Brasil. Biociências, vol. 8.

REIMCHE, GB., MACHADO, SLO., GOLOMBIESKI, JI., BAUMART, JS., BRAUN, N., MARCHESAN, E. and ZANELLA, R. 2008. Persistência na água e influência de herbicidas utilizados na lavoura arrozeira sobre a comunidade zooplanctônica de Cladocera,
Copepoda e Rotifera. Ciência Rural, vol. 38, no. 1, p. 7-13.

RODRIGUES, BN. and ALMEIDA, FS. 2005. Guia de herbicidas. 5th ed. Londrina: Ed. dos Autores. 592 p.

SCHULZ R, LIESS M. 1999. A field study of the effects of agriculturally derived insecticide input on stream macroinvertebrate dynamics. Aquatic Toxicology, 46, p.155-176.

SUHLING, F., BEFELD S., HAUSLER, M., KATZUR, K., LEPKOJUS, S., MESLÉARD, F. 2000. Effects of insecticide applications on macroinvertebrate density and biomass in rice-fields in the Rhone delta, France. Hydrobiologia, 431, p.69-79.

Sociedade Sul-Brasileira de Arroz Irrigado - SOSBAI. 2005. Recomendaçôes Técnicas da Pesquisa para o Sul do Brasil. Santa Maria, RS: SOSBAI. 159p.

Sociedade Sul-Brasileira de Arroz Irrigado SOSBAI. 2010. Recomendaçóes Técnicas da Pesquisa para o Sul do Brasil. Bento Gonçalves: SOSBAI. 188 p.

STENERT, C., BACCA, RC., MALTCHIK, L. and ROCHA, O. 2009. Can hydrologic management practices of rice fields contribute to macroinvertebrate conservation in southern Brazil wetlands? Hydrobiologia, vol. 635, p. 339-350.

TATUM, VL. 2004. Toxicity, transport, and fate of forest herbicides. Wildlife Society Bulletin, vol. 32, no. 4, p. 1042-1048. http://dx.doi.org/10.2193/00917648(2004)032[1042:TTAFOF]2.0.CO;2

VYAS, NB., THIELE, LA. and GARLAND, SC. 1998. Possible mechanisms for sensitivity to organophosphorus and carbamate insecticides in eastern screech-owls and American kestrels. Comparative Biochemistry and Physysiology, vol. 120, p. 151-157.

WAYLAND, M. and BOAG, DA. 1995. Fate of carbofuran and its effects on aquatic macroinvertebrates in Canadian prairie parkland ponds. Ecotoxicology, vol. 4, p. 169-189. http://dx.doi.org/10.1007/ BF00116480

WILLIAMS, DD. 1987. The Ecology of Temporary Waters. London: Croom Helm. 